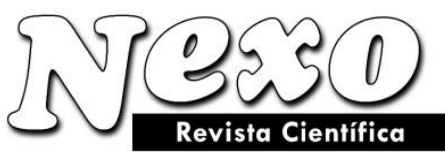

Vol. 34, No. 01, pp. 438-447/Marzo 2021

\title{
Improvement of the mechanism for managing the investment activities of an industrial concern
}

\section{Mejora del mecanismo de gestión de las actividades de inversión de una empresa industrial}

\author{
Marina Nikolaevna Kaloshina ${ }^{1^{*}}$, Vladislav Vyacheslavovich Gabuev ${ }^{1,2}$ \\ ${ }^{1}$ Moscow Aviation Institute MAI (National Research University), Moscow, Russia. \\ ${ }^{2}$ Almaz-Antey Management Consulting LLC, Moscow, Russia. \\ *kabuc@mail.ru
}

(recibido/received: 11-November-2020; aceptado/accepted: 07-January-2021)

\begin{abstract}
Competitive development of enterprises of the military industrial complex is determined by the implementation of promising investment projects. Amid a global reduction in military spending, military industrial enterprises need to improve their investment performance. This can be achieved due to a combination of factors, the strategic orientation of investment projects to the target guidelines for the organization's activities being the most important of them. In this regard, the issue of creating an efficient system for managing the investment activities of an enterprise becomes urgent, because such system would contribute to the strategic focus of the ongoing investment projects and efficiently and quickly meet modern challenges. An economic mechanism for managing investment activities and special business processes, as well as procedures for the development and implementation of investment projects and programs by the life cycle stages described through algorithms have been developed for this purpose based on L. Hurwitz's theory of economic mechanisms. The strategic analysis of the activities of a Russian military industrial concern has allowed to formulate the concept of managing the entire concern and to determine the principles, methods, and tools of the business process. Improving the system for managing a set of projects as part of implementing the strategic objectives of the concern has required to improve, streamline, and unify the entire strategic management toolkit in order to increase the investment performance, with due consideration of the role models of responsibility centers and the current legislation. The automated information systems for strategic development and investment project management have been designed based on the outcomes of the research.
\end{abstract}

Keywords: Differentiated Strategies; Mechanism For Managing; Investment Activities; Life Cycle of The Investment Project; Investment Program.

\section{RESUMEN}

El desarrollo competitivo de las empresas del complejo industrial militar está determinado por la implementación de proyectos de inversión prometedores. En medio de una reducción global del gasto militar, las empresas industriales militares deben mejorar el rendimiento de sus inversiones. Esto se puede lograr debido a una combinación de factores, siendo el más importante de ellos la orientación estratégica de los proyectos de inversión a las pautas objetivo para las actividades de la organización. En este sentido, se torna urgente el tema de la creación de un sistema eficiente para la gestión de las actividades de 
inversión de una empresa, porque dicho sistema contribuiría al enfoque estratégico de los proyectos de inversión en curso y afrontaría de manera eficiente y rápida los desafíos modernos. Para ello se ha desarrollado un mecanismo económico para la gestión de actividades de inversión y procesos comerciales especiales, así como procedimientos para el desarrollo e implementación de proyectos y programas de inversión por las etapas del ciclo de vida descritas mediante algoritmos basados en la teoría de los mecanismos económicos de L. Hurwitz. El análisis estratégico de las actividades de una empresa industrial militar rusa ha permitido formular el concepto de gestionar toda la empresa y determinar los principios, métodos y herramientas del proceso empresarial. Mejorar el sistema de gestión de un conjunto de proyectos como parte de la implementación de los objetivos estratégicos de la preocupación ha requerido mejorar, racionalizar y unificar todo el conjunto de herramientas de gestión estratégica con el fin de aumentar el rendimiento de la inversión, con la debida consideración de los modelos a seguir de responsabilidad. centros y la legislación vigente. Los sistemas de información automatizados para el desarrollo estratégico y la gestión de proyectos de inversión se han diseñado en base a los resultados de la investigación.

Palabras clave: Estrategias diferenciadas; Mecanismo de gestión; Actividades de inversión; Ciclo de vida del proyecto de inversión; Programa de inversiones.

\section{INTRODUCTION}

The management of many enterprises engaged in the production of military products is currently facing a number of problems arising in the process of managing investment activities. Achieving the strategic goals of large industrial enterprises and concerns of the military industrial complex is very important in the modern conditions. The strategic orientation of all ongoing investment projects is of particular importance due to limited resources and a decrease in the share of state funding. This means that the implementation of the entire set of projects accepted for implementation should contribute to the achievement of the company's strategic goals, which requires a special approach to the formation of a set of projects that can be implemented in the future (Isaev, 2016). In this regard, the issue of creating a system for managing the investment activities in the company becomes necessary, because such system would contribute to the strategic focus of the ongoing investment projects. At the same time, the investment performance largely depends on the standards and methods of investment management adopted in the organization.

At the same time, military industrial enterprises, many of which are core, often face a need to implement projects the efficiency of which is difficult to estimate using the traditionally used classical methods based on the concept of discounted cash flows and associated with calculating the financial effect, profitability, and payback periods (Damodaran, 2012). As such, the issue of the project efficiency does not always have an obvious solution based on the results of evaluating investment performance using classical methods. It must be noted that the economic efficiency of the project implementation does not always mean that project implementation is also financially efficient. Besides, many projects are related to the fulfillment by enterprises of various obligations and requirements of legislation and authorities. For example, the financial efficiency can be estimated only indirectly when a company builds a dormitory in pursuance of the requirements of the collective agreement on providing employees with housing, because cash flows must be built for the calculation of the classical indicators. There are no problems with the expenditure part of cash flows, but they arise when it comes to the revenue part. Of course, it can be equaled to the amount of penalties to be charged from the company in case of failure to fulfill its obligations - that is, a failure to fulfill a project, for example. However, an evaluation using classical indicators of investment performance will show in most cases that the implementation of the project is inefficient, even with this approach. This entails various difficulties in coordinating the implementation of such projects if the enterprise does not apply alternative methods for evaluating the investment performance, which means that projects with different focus and different objectives must be classified in accordance with the types of objectives for achieving which these projects are supposed to be implemented. The existence of 
different types of objectives for investment projects calls into question the efficiency of classical methods for evaluating investment performance and requires the development of new approaches to evaluating investment performance. At the same time, the existence of a large number of projects of different types with different objectives requires building an efficient management system capable of ensuring a customized approach to the processes of consideration and implementation of each project, regardless of its type and objectives, striving to implement truly important projects, the implementation of which will not only satisfy the various current needs of the company but will also contribute to the achievement of strategic goals. Taking into account the above problems, the efficiency of the investment activity management system can be achieved by creating an appropriate economic mechanism and developing business processes that ensure its operation.

The goal of the study is to improve and refine the entire investment management system in an industrial concern in order to ensure that the need to implement projects is more justified in achieving the strategic goals of an industrial concern, with due consideration of the need to respond to changing external and internal conditions.

In this regard, the ongoing investment projects in the concern under study, its existing business processes, subsystems, and elements, regulatory legislation for ensuring investment activities, the very investment activities of the concern and its subsystems, the connecting organizational functions, and the key financial and economic indicators of investment activities over time must be analyzed; the investment development strategies, strategic criteria, applied organizational procedures, and tools must be formulated and described; the economic mechanism and business processes for managing investment activities must be developed by life cycle stages, taking into account the portfolio approach, requirements for workflow, and organizational responses; possible management risks must be identified; the system for managing changes in the investment portfolio must be formulated.

\section{METHODS}

The analysis of the current mechanism for managing the investment activities of a large Russian military industrial concern indicated that the existing principles did not fully take into account the compliance of the projects accepted for implementation with the company's strategic goals. The current mechanism is based on the management of the investment project implementation in accordance with typical goals, while the mechanism under development should be focused on the management of investment programs in accordance with the development strategies of the concern.

All investments of the concern can be conditionally divided into several types for the purposes of managing the implementation of its investment projects: investment with economic return, investment with qualitative return, forced investment, and small investment.

Investment with economic return includes investment for which the cost and revenue components used to estimate the financial effect can be unambiguously determined. The decision to implement such projects is made on the basis of a comparison of economic return expressed using classical indicators of investment performance.

Investment with qualitative return includes investment for which the economic effect is difficult to estimate, but its implementation is necessary for objective reasons. For example, there is a need for reconstruction of capital facilities, re-equipment of production workshops, purchase of metrological instruments and special equipment, etc.

Forced investment includes investment that does not meet the requirements of economic efficiency but must be implemented in accordance with the obligations undertaken by the organization. 
Investment projects and programs at enterprises that are part of the structure of the analyzed concern can solve the following main tasks:

- tasks related to updating (simple, extensive, innovative, or mixed) of the technological equipment park, testing equipment, and measuring and control instruments;

- tasks related to the introduction of new technologies, including those introduced using the existing technological equipment park;

- tasks the solution of which ensures the improvement of management, organization of production, and logistics;

- tasks related to the reprofiling of sites, workshops, and enterprises in order to increase the use of production facilities;

- tasks of comparing technologies for manufacturing, repairs, and testing of standard parts and assemblies at different factories in order to select optimal solutions for cooperation.

Most enterprises do not have specialized systems for managing investment projects, and the accounting system does not provide for cost control in the context of projects. Therefore, it is difficult to trace the current state of a specific project, especially because a large number of projects can be underway at the same time at one enterprise.

There are two main approaches to the study of economic mechanisms in science at the moment. The first approach can be defined as informational in terms of its economic content and is explored in the works of L. Hurwitz (1993), R. Myerson (1981), E. Maskin (1999), - the 2007 Nobel laureates. The second approach, functional, was developed based on the works of the representative of the French economic school H. Culmann.

The authors study the approach of L. Hurwitz in more detail, as he introduced the concept of an economic mechanism. The chain of links "strategy - result" is considered as a mechanism in L. Hurwitz's works. At the same time, according to L. Hurwitz, a number of conditions must be observed to ensure the efficient operation of the mechanism: stable resource provision of the institutions that ensure the operation of the mechanism; sufficiency of information to analyze the efficiency of the mechanism; the quality of the legal framework.

The processes associated with the management of investment activities of an industrial concern and its subsidiaries were considered based on the approach proposed by L. Hurwitz. As such, in accordance with the above approach, a mechanism must be built that includes all the necessary elements to create the aforementioned chain of links, where the developed principles for managing the investment activities of the entire concern (including the enterprises included in the concern) will act as a "strategy", while the achievement of the strategic development goals of the concern, set out in the relevant internal corporate documents, will act as a "result".

\section{RESULTS}

The economic mechanism for managing the investment activities of a concern and its subsystems is considered in theory as a set of cause-and-effect relationships aimed at organizing and managing the business facility. In other words, a mechanism is a set of rules of the game. The rules of the game do not prescribe options for strategy and tactics of behavior. This role is assumed by various methodological 
toolkits. Strategic behavior is described using business processes that combine elements of the economic mechanism and detail the roles of the participants in relations, workflow, information architecture, and resources. Tactical variable behavior is described using algorithms that link every two elements of the mechanism. The set of algorithmic descriptions allows digitalization of the entire mechanism. The efficiency of the mechanism evaluation is ensured by qualitative and quantitative criteria that must be associated with each algorithm.

The developed mechanism for managing investment projects and programs is a unified system of interrelated key principles for managing investment activities, the observance of which ensures that the projects accepted for implementation meet all the necessary requirements, the strategic focus (Maskin, 1999) of investment projects accepted for implementation, and the continuity of updating annual investment plans and a long-term investment program. The following elements were provided during the development in the mechanism (Figure 1): differentiated strategies; investment portfolio; relevant investment program; investment budget; project implementation; monitoring, compensatory and preventive measures; achievement of the target results of the project implementation, successful completion of the project; updating the investment plan.

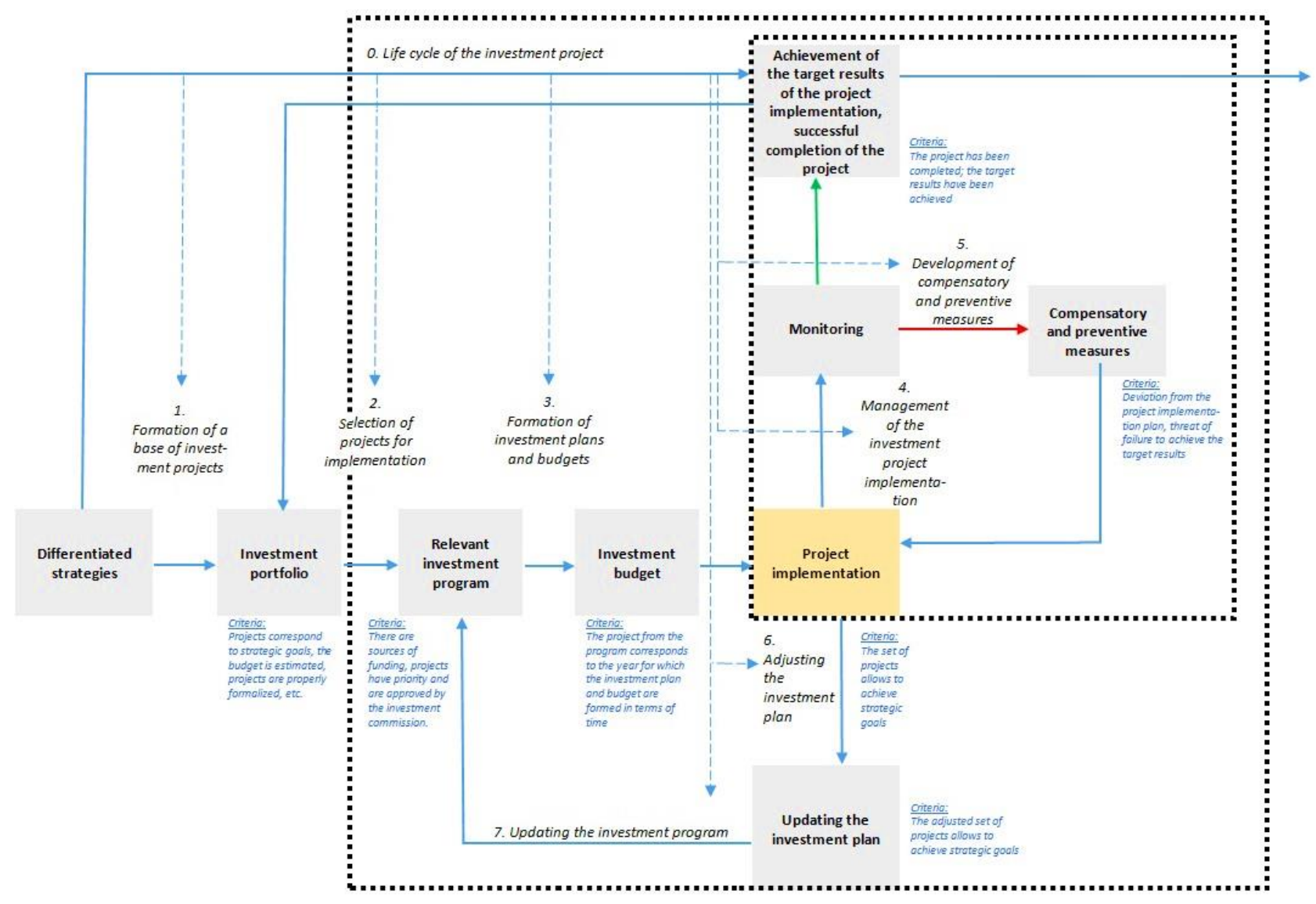

Figure 1. Mechanism for managing investment activities

A number of processes described through the specially developed algorithms for the actions of all participants in investment activities serve as the links among the elements of the mechanism. The implementation of these algorithms will ensure compliance with all the key principles embedded in the mechanism. The following processes act as links between the elements of the developed mechanism: formation of a base of investment projects; formation of an investment program; formation of investment 
plans and budgets; management of the investment project implementation; development of compensatory and preventive measures; adjusting the investment plan; updating the investment program.

The measures must be taken to systematize the development strategy, which is accepted as the basis of management in the developed mechanism, at the initial stage (element of the mechanism "Differentiated strategies"). The strategic goals are clarified or adjusted for this purpose, if necessary. This is done by differentiating strategic goals according to various criteria and determining the most appropriate type of strategy at the moment (technical, technological, financial, economic, etc.), as well as analyzing and assessing risks and identifying weaknesses and threats.

This procedure will allow to assess the need for various activities to achieve each of the set strategic goals in the conditions of limited resources (primarily financial and human), as well as to understand on which area the company's efforts must be focused by attracting the necessary resources (finance, production capacity, personnel, etc.). The most suitable type of strategy is determined based on the information obtained during the procedure execution and in accordance with the typology of strategies by commonly known qualitative characteristics, which serves as the basis for the further development of the strategy for the entire industrial concern and individual enterprises.

The element of the mechanism "Differentiation of strategies" is linked with the next element "Investment portfolio" through the formation of a base of investment projects (Algorithm 1 in Figure 1). This means that the algorithm for forming a base of investment projects must be executed in order to proceed to the next stage, which includes the totality of all projects that can be implemented. This algorithm is designed in such a way that the results of executing the sequence of actions inherent in it lead to the implementation of the key principles laid down in the next block of the mechanism (Kaloshina, Gabuev, 2019b). The implementation of the procedures for the formation of the base of investment projects in this particular case leads to the results that correspond to a number of specially formulated criteria: the selected projects must be properly formalized, correspond to the strategic goals, and all the indicators must be estimated that are required to account for the financing of this project if it is accepted for implementation in the appropriate budget. The formed investment portfolio, which includes a number of investment projects corresponding to the specific strategic goals of the concern that can be further accepted for implementation, is the immediate result of the algorithm execution.

The element of the mechanism "Investment portfolio" is linked with the element "Relevant investment program" through the selection of projects for implementation (Algorithm 2). This means that a properly formed investment program should include only projects that are relevant and important for the entire concern or its enterprises in particular, which have priority over other projects included in the investment portfolio but not included in the investment program. Such projects must be approved by the investment commission in the manner prescribed by the algorithm; the sources of funding of their implementation must be determined. The formed investment program of the concern - a list of projects that were selected from the investment portfolio based on their priority importance and availability of funding sources - is the immediate result of the selection of projects for implementation. The projects that were not included in the investment program are sent for revision. They remain included in the investment portfolio and can be accepted for implementation in the future.

The element of the mechanism "Relevant investment program" is linked with the element "Investment budget" through the formation of investment plans and budgets (Algorithm 3). This means that the projects included in the investment program and accepted for implementation should be promising, taking into account the circumstances prevailing at the time of the project launch (Kaloshina, Gabuev, 2019a). Since the investment program is formed for a medium-term period (five years), the launch of the investment project can be scheduled for the next or any other year of the program. In this regard, the formation of annual investment plans is provided, according to a specially developed algorithm. Each 
investment project included in the investment program undergoes a number of procedures before being included in the investment plan of the corresponding year, including adjustments to the project, taking into account changes in external and internal conditions. The formed investment plan for the corresponding year, coupled with the budget for this year, is the immediate result of the Algorithm 3 execution.

"Project implementation" is the next element of the mechanism. The current set of projects accepted for implementation should secure the achievement of certain strategic goals. However, situations may arise due to changes in external and internal conditions and due to the long duration of the investment program and investment plan, in which the current set of projects does not fully secure the achievement of the strategic goals of the entire concern or of an individual enterprise. In this regard, the set of projects implemented in the short term (up to one year) must be regularly updated. Therefore, the developed mechanism provides for the continuation of the further implementation of all approved investment projects according to Algorithm 4 and, as a consequence, implementation of each of the projects, on the one hand; while the mechanism includes an algorithm for adjusting the investment plan (Algorithm 6), which ensures the regular update of the set of projects being implemented (element "Updating the investment plan"), on the other hand. As such, the mechanism provides for two further directions: from the element of the mechanism "Project implementation" to the element "Monitoring" and further; from the element "Project implementation" to the element "Updating the investment plan" through the "Adjusting the investment plan" algorithm, the implementation of which allows to select projects that must be included in the investment plan on an extraordinary basis, from the previously formed investment portfolio, as well as to exclude projects the implementation of which was refused.

The element "Updating the investment plan" is linked with the element "Relevant investment program" through updating the investment program (Algorithm 7). The influence of changing conditions may necessitate changes not only within the current year, but also in the medium term - therefore, the algorithm for updating the investment program provides for the inclusion of previously considered projects from the investment portfolio in the program. Besides, changes in the investment plan also entail updating the medium-term investment program and the inclusion of projects previously included in the investment plan. The updated investment program is the immediate result of executing Algorithm 7. The projects included in the investment program in the process of its updating should then be accepted for implementation - therefore, firstly, they must meet the criteria required for the implementation of the principle laid down in the element "Relevant investment program", and, secondly, they must pass all subsequent algorithms up to the achievement of the target results of the implementation of these projects and the completion.

The project implementation plan is continuously monitored during the implementation of investment projects - therefore, the element of the mechanism "Project implementation" is associated with the "Monitoring" element. Risks and various deviations from the investment project implementation plan can be identified during monitoring. In this regard, compensatory and preventive measures become necessary. This determines the following variable branching of the mechanism: in the absence of risks and deviations, the implementation of the project continues in accordance with the plan, the target results are achieved, and the project is successfully completed (element "Achievement of the target results of the project implementation, successful completion of the project"); or compensating and preventive measures are developed in accordance with the developed diagram of the business process, the project implementation plan is adjusted, the developed measures are taken (element "Compensatory and preventive measures"), and the project continues in accordance with the adjusted plan. The algorithm "Management of the investment project implementation", developed in the course of the study, links the elements "Project implementation" and "Monitoring" and continues in the form of developing compensatory and preventive measures, if necessary. 
As such, the management of the investment project implementation is described using the algorithm for managing the investment project implementation (Algorithm 4-5), linking the elements "Project implementation", "Monitoring", and "Compensatory and preventive measures".

Algorithm 4-5, presented in Figure 2, regulates the process of managing the investment project implementation from the moment the project launches to the moment it completes. This algorithm includes determination of the form of project management, appointment of its manager, development of the project management regulation, identification of risks and deviations from the project implementation plan, analysis of the causes of deviations, development of compensatory and preventive measures, etc.

The process of the investment project implementation begins with defining the form of managing the new investment projects. The implementation of investment projects that make up an investment program can be managed using project management (Order of the Government of the Russian Federation No. ISH-P134148 , 2015). Project reporting is generated based on the monitoring data. The project manager, the investment department of the parent organization of the concern, and financial and economic divisions identify the risks of the project and deviations of the actual implementation of the project from the implementation plan, based on the information contained in the reporting on investment projects. In case of any deviations, the project manager and the investment department of the parent organization of the concern analyze the reasons that caused such deviations.

Based on the identified deviations of the actual project implementation from the plan, the project manager and the investment department develop measures aimed at eliminating the consequences of deviations and at returning the progress of the project to the target framework. Compensatory measures are an integral part of the management plan of the investment project implementation, approved and updated by the investment commission.

Based on the identified risks, the project manager and the investment department of the parent organization develop measures to minimize the consequences of the risk in the event of their occurrence or to prevent the risk (depending on the risk acceptance policy). In accordance with the reasons for identified deviations, measures are being developed to prevent such deviations in the future. Preventive (both in terms of risks and deviations) and compensatory measures are an integral part of the management plan of the investment project implementation.

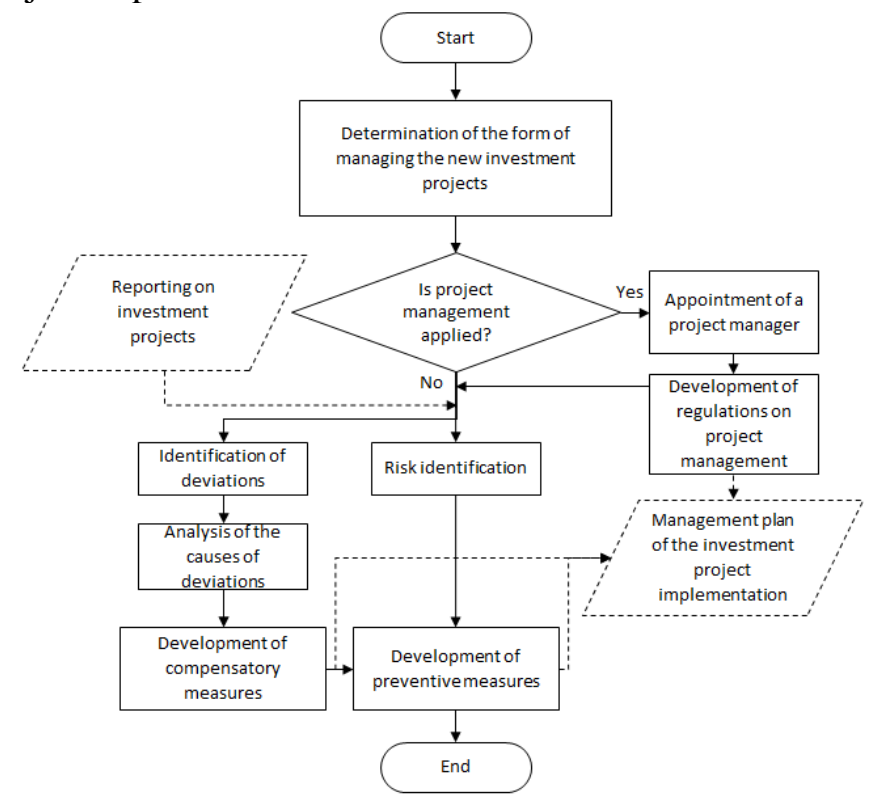

Figure 2. Algorithm for managing the investment project implementation 
The achievement of the target results of the project implementation and the formation of appropriate reporting are the results of the algorithm implementation. As such, the developed mechanism for managing investment activities is completed by the implementation of this algorithm. The application of the principles of the investment activity management mechanism ceases once the results of the project are achieved.

The set of all algorithms and processes that form the investment activity management mechanism represents the life cycle (Ermakova, Ruban, 2020) of an investment project and contains all the procedures that an investment project must undergo from its initiation and the formation of an investment proposal until the final completion.

Two profiles can be conventionally distinguished in the developed mechanism: the first is a large profile, which includes elements and links aimed at maintaining the relevance of the adopted investment plans and programs, including their implementation as a set of the ongoing projects. The second profile, small, includes elements and links directly related to the implementation of specific investment projects.

\section{DISCUSSION}

The mechanism represented by a set of cause-and-effect and feedback relationships and principles aimed at organizing and managing the economic process is detailed using the corresponding business processes that have been developed for each of the parts of the mechanism, included in large and small profiles. The business process is considered as a set of interrelated actions aimed at creating a certain result, which represents the implementation of investment projects and programs in the concern and its subsystems. It is advisable to consider the following business processes: the business process for managing the implementation of investment programs and the business process for managing the implementation of investment projects. The developed business processes are horizontally differentiated by the subjects of relations and are supplemented by the workflow arising during the implementation of the business process.

As such, the conducted strategic analysis of the activities of the concern and its subsystems has allowed to formulate the concept of managing the entire concern and to determine the principles, methods, and toolkits of business processes. Strategic analysis involves the systematization of the general goals and objectives of the concern operation, the list of which determines the tactical steps for the implementation of each investment project from its initiation until making a decision to include the project in the single investment portfolio, taking into account the justification of funding sources and launching the project into development. The developed mechanism for managing the investment activities of the industrial concern allows to build an integral management system that allows to integrate the implementation of investment projects of all enterprises of the concern into the single strategy and to efficiently respond to changes in external conditions. Improving the investment management system also includes the development of business processes for the implementation of investment projects and programs in the concern in the following main areas: development of procedures for the formation and implementation of investment projects and programs by the life cycle stages, which include an algorithm for forming a base of investment projects, an algorithm for selecting projects for implementation, procedures for the formation of an investment plan and budget, procedures for managing the implementation of investment projects, analysis of deviations, and development and implementation of compensatory measures.

\section{CONCLUSION}

The directions for improving the organizational structure in terms of improving the management of investment processes have been formulated, based on the obtained results (Dang, Pekkola, 2017). Requirements for the functions and powers of persons responsible for improving investment performance 
have been determined, and the requirements for the principles of improving the criteria for the work of personnel, workflow, and timing of duties have been formulated, with due consideration of the level of responsibility and subordination in accordance with business processes for managing investment projects and programs.

\section{REDERENCES}

Damodaran, A. (2012). Investment Valuation: Tools and Techniques for Determining the Value of Any Asset. New York: Wiley.

Dang, D., Pekkola, S. (2017). Enterprise Architecture and Organizational Reform: A Project Debrief. PACIS 2017 PROCEEDINGS, 71.

Ermakova, O.V., Ruban, N.V. (2020). Improving the terms of the life cycle contract for the creation of complex technical objects in high-tech industries. Journal of Physics: Conference Series, 1515(3). Retrieved from: https://iopscience.iop.org/article/10.1088/1742-6596/1515/3/032017

Hurwicz, L. (1993). Toward a Framework for Analyzing Institutions and Institutional Change, in: Markets and Democracy (S. Bowles, H. Gintis, B. Gustafson (eds.)). Cambridge: Cambridge University Press.

Isaev, D.V. (2016). Korporativnoye upravleniye i strategicheskiy menedzhment. Informatsionnyy aspekt [Corporate governance and strategic management. Information aspect]. Moscow: Higher School of Economics (State University).

Kaloshina, M.N., Gabuev, V.V. (2019a). Sovershenstvovaniye sistemy upravleniya biznes-protsessom realizatsii investitsionnykh proyektov $\mathrm{i}$ programm $\mathrm{v}$ kontserne [Improving the business process management system for the implementation of investment projects and programs in a concern]. Economics and Entrepreneurship, 10.

Kaloshina, M.N., Gabuev, V.V. (2019b). Sovershenstvovaniye protsessa planirovaniya investitsionnoy deyatelnosti $\mathrm{v}$ kontserne [Improving the planning process for investment activities in a concern]. Economics and Entrepreneurship, 10.

Maskin, E. (1999). Nash Equilibrium and Welfare Optimality. Review of Economic Studies, 66(1), 23-38. Myerson, R. (1981). Optimal Auction Design. Mathematics of Operation Research, 6(1), 58-73.

Order of the Government of the Russian Federation No. ISH-P13-4148. (June 24, 2015). Guidelines for the preparation of regulations for improving investment and operating performnace and reducing costs. 